\title{
Beverage quality of most cultivated Coffea canephora clones in the Western Amazon
}

\author{
Janderson Rodrigues Dalazen' (iD), Rodrigo Barros Rocha² (iD), Lucas Louzada Pereira ${ }^{3}$ (i), Enrique Anastácio Alves² (iD, \\ Marcelo Curitiba Espindula ${ }^{2}$ (D), Carolina Augusto de Souza ${ }^{1}$ (D)
}

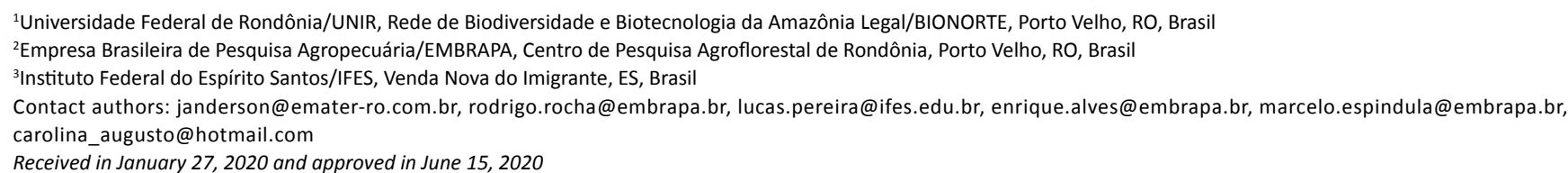

\section{ABSTRACT}

Most of the Western Amazon coffee production is made from growing unregistered clones, selected by the coffee growers themselves. The aim of this study is to evaluate the sensory profile and genetic diversity of the most cultivated Coffea canephora clones in the Western Amazon. Coffee samples at cherry stage of the clones $03,05,08,25$ and 66 were collected at eight municipalities in the main coffee growing zones, with altitudes ranging from 86 to 381 meters. Beverage quality was evaluated according to the Robusta Cupping Protocols and estimates of the genotype $\times$ environment interaction (GE) were made interpreting non-parametric and multivariate methods. The GE interaction was significant and the genetic component was also important to the expression of beverage quality $\left(h^{2}=82,23\right)$. The clones 25 and 05 have good attributes and mean score near 80 points. Sweetness was the sensory descriptor with the greatest impact on beverage quality of these two clones. Harshness was the descriptor that had the greatest negative impact on beverage quality of clone 66 . The clones had complexities that differed and that were not necessarily associated with greater beverage quality. Despite the differences in their beverage attributes, these clones that are grown for their high productivity presented low genetic diversity of the beverage quality.

Key words: Fine robusta coffee; sensory analysis; genetic parameters.

\section{INTRODUCTION}

Brazil is the second largest coffee producer of the species Coffea canephora with production of 14.3 million bags $(60 \mathrm{~kg})$ of hulled coffee (Companhia Nacional de Abastecimento - CONAB, 2019). The economic importance of this coffee is mainly due to its use as a basic raw material in the soluble coffee industry and as an important component in the composition of blends with the Coffea arabica (Ribeiro et al., 2014).

The Western Amazon, composed of the States of Amazonas, Acre, Rondônia and Roraima, represents 42.97\% of the Brazilian Amazon territorial extension (Superintendência da Zona Franca de Manaus - SUFRAMA, 2017). In this region coffee of the species C. canephora is produced, especially in Rondônia, which produces 2.3 million bags, equivalent to $90 \%$ of the region's coffee (CONAB, 2019). The clones grow in the state of Rondônia have become the genetic basis for renewing coffee plantations across the Western Amazon (Espindula et al., 2017; Dalazen et al., 2019).

The $C$. canephora species has two distinct botanical varieties grown commercially, called Conilon and Robusta (Ramalho et al., 2016; Rocha et al., 2013). The Conilon botanical variety has shrub-like growth, early flowering, elongated leaves, drought resistance, and greater susceptibility to diseases. The Robusta botanical variety, for its part, has greater vigor, larger leaves and fruit, late maturity, lower tolerance to water deficit and greater disease tolerance (Ferrão et al., 2013; Montagnon; Cubry; Leroy, 2012). While the Conilon botanical variety has a predominance of neutral, less full-bodied beverages, the Robusta botanical variety is distinguished by exotic nuances identified as fruity, chocolate and almonds (Souza et al., 2018a). Hybridization between these two varieties occurs naturally in the field, producing genotypes that can exhibit the best traits of each one of the groups (Ramalho et al., 2016; Dalcomo et al., 2015).

In 2010, the Robusta Cupping Protocol was developed, which presents specific evaluation criteria for C. canephora beverages, standardizing the beverage upon considering the characteristic variations of this species (Uganda Coffee Development Authority - UCDA, 2010). The main sensory attributes of the $C$. canephora beverages are fragrance/aroma, flavor, aftertaste, salinity/acidity relationship, bitterness/sweetness relationship, mouth sensation, balance, uniformity, cleanness, and the overall result. The sum of all the scores, evaluated in scales ranging from 0 to 10 , is used to obtain the final grade used to classify the beverage regarding its quality (UCDA, 2010).

Evaluations of beverage quality presented by Souza et al. (2018a) for the botanical varieties Conilon and Robusta and the intervarietal hybrids showed that nuances of the Conilon botanical variety were predominantly neutral (78\%) compared to the Robusta botanical variety and intervarietal hybrids, which had $50 \%$ and $44 \%$, respectively, of nuances classified as fruity, exotic, or mild. 
In the Western Amazon most of the coffee is produced from growing unregistered clones selected by the coffee growers themselves. According to Dalazen et al. (2019), coffee growing in the state is based on five predominant genotypes; clones 08 and 25 are present in $89 \%$ of the fields, and clones 03,66 , and 05 are present in $80 \%, 63 \%$, and $41 \%$ of the fields, respectively.

Beverage quality is a trait affected both by the genotype and the environment, since aroma and flavor of the coffee beans are also affected by edaphic and climatic conditions (Sunarharum; Williams; Smyth, 2014; Santos et al., 2011). Important environmental factors include the soil, altitude, cultivar, management practices, ripening, processing, drying, hulling, storage, and roasting, which interact with each other and affect coffee quality at different intensities (Giomo; Borém, 2011; Verdin Filho et al., 2016). Main differences in beverage quality among the genotypes of Coffea sp. are due to differences in their genetic constitution (Moschetto et al., 1996), which exhibit differentiated expression in the environments in which the coffee is grown (Laviola et al., 2007; Fonseca et al., 2019).

Differential response of the plants to environmental variations makes it necessary to consider the genotype $x$ environment interaction in the plant performance in different environments (Ten Caten et al., 2011; Rocha et al., 2015). Significant effects of the genotype $\times$ environment interaction are the result of the non-additive relationship of the genotype and environment effects caused by change in plant performance in different locations (Resende, 2002; Rocha et al., 2016).

In this scenario, the objective of this study is characterize the sensory profile and quantify the genetic parameters related to beverage quality of the $C$. canephora clones most grown in the Western Amazonia.

\section{MATERIAL AND METHODS}

\subsection{Genetic material}

The clones $03,05,08$, and 25 selected by coffee growers in the municipality of Nova Brasilândia do Oeste,
RO are present in over $89 \%$ of the fields (Table 1 ). The first seedlings of these clones were produced in 1999/2000, and the commercial production began in 2005 (Dalazen et al., 2019). The clone 66 was selected by coffee growers in the municipality in the municipality of Alta Floresta do Oeste, RO. The first clonal seedlings were produced in 1998, and the first commercial production occurred in 2008 (Dalazen et al., 2019) (Table 1). All clones have hybrid traits between the botanical varieties Conilon and Robusta.

\subsection{Collection of samples and sensory analysis}

In 2019 the coffee fruit was collected on family farm properties at the third crop year, managed according to recommendations of Marcolan et al. (2009) (Table 2). Three replications of six liters of coffee fruit per clone were collected in each farm. The coffee fruits were harvested at the cherry stage (M3 maturity stage), and washed to remove the buoy fruits, separating impurities (leaves, stones, sticks, earth), green fruits and nuts. The fruits were placed to dry through dry process (natural processing) in "barge-type" (transparent mobile) covering until the samples reached $11-12 \%$ moisture, by natural processing drying (Morais et al., 2008). The coffee was hulled in the laboratory of Embrapa Rondônia, Ouro Preto do Oeste, RO campus. Then the coffee beans were sieved (sieve 15 and higher) and packaged in $0.5 \mathrm{~kg}$ samples.

Climate in the region is Aw (Köppen classification), defined as tropical humid, with rainy season (October to May) in the summer and dry season in the winter (Alvares et al., 2013). Mean annual temperature ranges from $23.1{ }^{\circ} \mathrm{C}$ to $26.0{ }^{\circ} \mathrm{C}$, and the highest temperatures occur in July and August. Mean annual rainfall is $1921 \mathrm{~mm}$, with mean relative humidity of $81 \%$ (Table 2 ).

Sensory analysis of the samples was performed in the Coffee Analysis and Research Laboratory (Laboratório de Análise e Pesquisa em Café - LAPC) of the Instituto Federal do Espírito Santo, Venda Nova do Imigrante campus by six judges/cuppers (R Grader) (Pereira et al., 2018a; Pereira et al., 2019), according to the Robusta Cupping Protocol of the Coffee Quality Institute - CQI (Uganda Coffee Development Authority - UCDA, 2010).

Table 1: Characteristics of the main clones of $C$. canephora grown in the Western Amazon.

\begin{tabular}{|c|c|c|c|c|c|}
\hline Clone & Size & Maturity & Fruit & Main characteristic & Presence in field $(\%)$ \\
\hline 03 & Medium & Intermediate & Medium & High production per branch & $80 \%$ \\
\hline 05 & Medium & Intermediate & Medium & Hardiness against attack from disease & $41 \%$ \\
\hline 08 & Medium & Intermediate & Large & Vigor and high yield & $89 \%$ \\
\hline 25 & Medium & Intermediate & Large & High yield of coffee beans from hulling & $88 \%$ \\
\hline 66 & Short & Early & Small & High yield of coffee beans from hulling & $64 \%$ \\
\hline
\end{tabular}

Source: Dalazen et al. (2019). 
Table 2: Altitude, sample collection coordinates, mean temperature, annual rainfall and coffee production in the different environments in the Western Amazon.

\begin{tabular}{|c|c|c|c|c|c|}
\hline Environment & Altitude (m) & Coordinates & Mean temperature $\left(\mathrm{C}^{\circ}\right)$ & Annual rainfall (mm) & Production (60 kg bags) \\
\hline Alto Alegre dos Parecis & 381 & $\begin{array}{l}12^{\circ} 07^{\prime} 41^{\prime \prime} \mathrm{S} \\
61^{\circ} 51^{\prime} 02^{\prime \prime} \mathrm{O}\end{array}$ & 23.1 & 1735 & $131,364(6.8 \%)$ \\
\hline Alto Paraíso & 127 & $\begin{array}{l}09^{\circ} 42^{\prime} 47^{\prime \prime} \mathrm{S} \\
63^{\circ} 19^{\prime} 15^{\prime \prime} \mathrm{O}\end{array}$ & 25.6 & 2302 & $1,721(0.1 \%)$ \\
\hline Cacoal & 179 & $\begin{array}{l}11^{\circ} 26^{\prime} 19^{\prime \prime} \mathrm{S} \\
61^{\circ} 26^{\prime} 50^{\prime \prime} \mathrm{O}\end{array}$ & 24 & 1899 & $276,581(14.3 \%)$ \\
\hline Nova Brasilândia do Oeste & 263 & $\begin{array}{l}11^{\circ} 43^{\prime} 25^{\prime \prime} \mathrm{S} \\
62^{\circ} 18^{\prime} 57^{\prime \prime} \mathrm{O}\end{array}$ & 24 & 1799 & $206,542(10.7 \%)$ \\
\hline Ouro Preto do Oeste & 237 & $\begin{array}{l}10^{\circ} 44^{\prime} 53^{\prime \prime} \mathrm{S} \\
62^{\circ} 12^{\prime} 57^{\prime \prime} \mathrm{O}\end{array}$ & 24.3 & 1922 & $1,922(0.1 \%)$ \\
\hline Porto Velho & 86 & $\begin{array}{l}08^{\circ} 45^{\prime} 43^{\prime \prime} \mathrm{S} \\
63^{\circ} 54^{\prime} 07^{\prime \prime} \mathrm{O}\end{array}$ & 26 & 2095 & $66,645(3.4 \%)$ \\
\hline Rolim de Moura & 210 & $\begin{array}{l}11^{\circ} 43^{\prime} 48^{\prime \prime} \mathrm{S} \\
61^{\circ} 46^{\prime} 47^{\prime \prime} \mathrm{O}\end{array}$ & 23.9 & 1864 & $45,493(2.4 \%)$ \\
\hline São Miguel do Guaporé & 194 & $\begin{array}{l}11^{\circ} 41^{\prime} 37^{\prime \prime} \mathrm{S} \\
62^{\circ} 42^{\prime} 41^{\prime \prime} \mathrm{O}\end{array}$ & 24.6 & 1758 & $356,160(18.4 \%)$ \\
\hline State of Rondônia & 217 & & 25.3 & 1939 & $1,938,200$ \\
\hline
\end{tabular}

Altitude and Climate Data (Alvares et al., 2013), Coffee production data (Conab, 2019).

The toasts were conducted using the Laboratto, modeloTGP-2 (approximately 10 minutes at $190^{\circ} \mathrm{C} \pm 10^{\circ} \mathrm{C}$ ). The roasting was monitored by a set of Agtron-SCA discs, and the roasting point of these samples was between the colors determined by discs \# 65 and \# 55, for specialty coffees (Specialty Coffee Association of America - SCA, 2013).

The samples were evaluated between 08 and 24 hours after the roasting of the grains. The coffee samples were ground with a Bunn, modelo G3, with medium / coarse grain size. Each sample was tasted with 5 cups, adopting the concentration of $0.008 \mathrm{~kg}$ of ground coffee in $150 \mathrm{~mL}$ of water, in accordance with the midpoint of the balance graph (SCA, 2013). The water infusion point was made after the water reached $92.2-94.4{ }^{\circ} \mathrm{C}$. The tasters started the evaluations when the temperature of the cups reached $55^{\circ} \mathrm{C}$, respecting the time of 4 minutes for tasting after the infusion.

The attributes evaluated were fragrance, flavor, acidity, bitter, mouthfeel, balance, aftertaste, uniform cup, clean cup, and overall UCDA (2010). The final grade of beverage quality is estimated from the sum of each attribute scores evaluated individually on a scale ranging from 0 to 10 .

\subsection{Statistical analyses}

Individual variance analyzes were interpreted to evaluate the experimental accuracy and the significance of the clones effects in each environment. After checking the homogeneity of the residual variances, a two-way analysis of variance was carried out for quantification of the effect of the genotype $\mathrm{x}$ environment interaction, according to the model described by Cruz, Carneiro and Regazzi (2014) (Equation 1):

$Y_{i j k}=m+G_{i}+A_{j}+G A_{i j}+E_{i j k}$

where $Y_{i j k}$ refers to the beverage quality of the i-th genotype in the $\mathrm{j}$-th environment in the $\mathrm{k}$-th replication; $m$ is the experimental mean; $G_{i}$ is the effect of the i-th genotype (clone); $A_{j}$ is the effect of the $\mathrm{j}$-th environment; $G A_{i j}$ is the effect of the interaction between the i-th genotype and the $\mathrm{j}$-th environment; and $E_{i j k}$ is the experimental error.

To quantify the contribution of the environments on the genotypes performance, the environmental quality index $\left(I_{j}\right)$ was interpreted, which was estimated from the following expression (Eberhart; Russell, 1966) (Equation 2):

$I_{j}=\bar{y}_{j}-\bar{y}$

where $I_{j}$ is the environmental classification index; $\bar{y}_{j}$ is the overall mean of the genotypes in the $\mathrm{j}$-th environment, and $\bar{y}$ is the overall mean of the genotypes in all the environments. The index classifies the environments in which $I_{j}$ is greater than or equal to zero as favorable, and environments with negative $I_{j}$ as unfavorable.

Stability and adaptability estimates of the centroid method were obtained considering data vectors containing maximum and minimum genotype performances in each environment. From these vectors, ideal references were 
obtained, using the minimum, medium and maximum performances in favorable and unfavorable environments (Rocha et al., 2005; Nascimento et al., 2015). The clones under evaluation were classified considering the Euclidean distance of each genotype in relation to the known behavior references (centroids), according to the Equation 3:

$$
D_{i k}=\sqrt{\sum_{j=1}^{n}\left(X_{i j}-C_{j k}\right)^{2}}
$$

Where: $X_{i j}$ : quality final score of the ith-genotype in the $j$-th environment, $C_{j k}$ quality final score of the kth-centroid in the $\mathrm{j}$-th environment, $\mathrm{D}_{\mathrm{jk}}$ is the distance from the ith genotype to the $\mathrm{kth}$ centroid $(\mathrm{k}=1,2, \ldots \mathrm{n})$ : I: high overall adaptability; II: favorable environment-specific adaptability; III: unfavorable environment-specific adaptability; IV: poorly adapted.

The dispersion in the plane was obtained using the principal component technique observations size equal to the number of evaluated genotypes, plus six additional lines corresponding to the reference points (Hair et al., 2009). For quantification of the adaptability and stability of the beverage quality, was also interpreted the estimator proposed by Lin and Binns (1988). The analyzes were performed using the GENES software (Cruz; Carneiro; Regazzi, 2014).

\section{RESULTS AND DISCUSSION}

Individual variance analyzes were interpreted to evaluate the experimental accuracy and the post-harvest procedures (Table 3 ). Estimates of heritability $\left(\mathrm{h}^{2}\right)$ and of the experimental coefficient of variation $\left(\mathrm{CV}_{\mathrm{e}}\right)$ indicated that the post-harvest procedures were adequate in the evaluated environments. Higher estimates of the coefficient of variation were observed by (Souza et al., 2018a) in the evaluation of 130 C. canephora accessions in a single environment.

The environments of Alto Paraíso, Nova Brasilândia, Ouro Preto do Oeste, Porto Velho, and Rolim de Moura positively contributed to an increase in beverage quality, while Alto Alegre dos Parecis, São Miguel do Guaporé and Cacoal had a negative environmental effect on the quality score (Table 3 ). The difference of the final grades between the best and the worst environment is 2.6 points $\left(\mathrm{FS}_{\mathrm{A} 3}=76.0, \mathrm{FS}_{\mathrm{A} 5}=78.6\right)$. This small difference can be explained by the low altitude variation and similarity in temperature and precipitation conditions.

Several studies report the effects of the solar irradiation and temperature on the quality of the coffee beverage which affects fructification and the ripening time (Sturm et al., 2010; Silveira et al., 2016; Pereira et al., 2018b). In regions with mild temperatures, the ripening process is slower resulting in greater accumulation of biochemicals associated with beverage quality
(Laviola et al., 2007). The literature relates more extensively environmental factors and the beverage quality of $C$. arabica. Avelino et al. (2002) worked with cafés-terroir in Honduras and found that higher altitudes (lower temperatures) favored quality, producing a characteristic flavor and aroma, and that the rainfall factor was considered negative. Menchú and Ortega (1971) in studies conducted in Guatemala with samples from the southwest coast in an altitude range of 300 to 1500 meters discovered that altitude variations also result in changes in beverage characteristics. Aroma, acidity, and the body of the coffee beverage gradually increase with altitude, until arriving at maximum values. Similar results were found by Cabrera, Acevedo and Lacerra (1991) in their studies conducted in the mountainous area of Cuba and by Buenaventura and Casteño (2002) in Colombia in crops planted at three different altitudes. Others studies also observed that the higher the altitude, the higher the scores for beverage quality in arabica coffee (Barbosa et al., 2012, Borém et al., 2019; Rodrigues et al., 2016).

Table 3: Summary of the beverage quality final score of $C$.

\begin{tabular}{ccccccccc} 
canephora & clones & \multicolumn{2}{c}{ grown } & in & the & \multicolumn{2}{c}{ Western } & \multicolumn{2}{c}{ Amazon. } \\
\hline Environment & $\mathrm{FS}_{\text {mean }}$ & $\mathrm{FS}_{\max }$ & $\mathrm{FS}_{\min }$ & $\mathrm{I}_{\mathrm{j}}$ & $\mathrm{CV} \%$ & $\mathrm{~F}$ & $\mathrm{~h}^{2}$ \\
\hline $\mathrm{A}_{1}$ & 76.4 & 78.7 & 74.3 & -0.88 & 1.51 & $8.10^{* *}$ & 91.6 \\
$\mathrm{~A}_{2}$ & 77.6 & 81.4 & 75.1 & 0.39 & 2.08 & $16.57^{* *}$ & 91.9 \\
$\mathrm{~A}_{3}$ & 76.0 & 79.7 & 70.5 & -1.20 & 1.73 & $37.94^{* *}$ & 97.6 \\
$\mathrm{~A}_{4}$ & 77.3 & 79.8 & 75.3 & 0.02 & 1.94 & $13.02^{* *}$ & 91.1 \\
$\mathrm{~A}_{5}$ & 78.6 & 81.2 & 75.8 & 1.39 & 2.17 & $15.65^{* *}$ & 90.4 \\
$\mathrm{~A}_{6}$ & 78.2 & 79.7 & 76.7 & 1.02 & 1.45 & $4.39^{* *}$ & 84.8 \\
$\mathrm{~A}_{7}$ & 77.3 & 79.5 & 73.3 & 0.07 & 1.84 & $18.10^{* *}$ & 94.2 \\
$\mathrm{~A}_{8}$ & 76.4 & 80.6 & 72.0 & -0.81 & 1.53 & $36.26^{* *}$ & 98.1 \\
\hline
\end{tabular}

$A_{1}$ : Alto Alegre dos Parecis - RO, $A_{2}$ : Alto Paraíso - RO, $A_{3}$ : Cacoal - RO, $A_{4}$ : Nova Brasilândia - RO, $A_{5}$ : Ouro Preto do Oeste - RO, $A_{6}$ : Porto Velho - RO, $A_{7}$ : Rolim de Moura - RO, $A_{8}$ : São Miguel do Guaporé - RO. $\mathrm{FS}_{\text {mean }}$ : Mean final score, $\mathrm{FS}_{\max }$ : Maximum final score, $\mathrm{FS}_{\min }$ : Minimum final score, I: environmental index, CV\%: coefficient of variation percentage, $\mathrm{F}$ : $\mathrm{F}$ test of analysis of variance, $\mathrm{h}^{2}$ : mean heritability of the clones.

Sturm et al. (2010) also evaluated the sensory attributes of different $C$. canephora clones grown at different altitudes ( 0 to 250,250 to 500 and above 500 meters of altitude). These authors reported significant differences at higher altitudes, where the beverage exhibited positive attributes.

The estimates of the $\mathrm{F}$ test for the genotype $\times$ environment interaction were significant at $1 \%$ probability. The significance of the genotype $\times$ environment interaction indicates the differentiated response of the clones in the environments and that the performance of the genotypes must be evaluated individually (Table 4). 
Table 4: Summary of ANOVA of the effects of genotypes, of environments, and of the genotype $\times$ environment interaction in expression of beverage quality of the five main clones grown in the Western Amazon.

\begin{tabular}{ccccc}
\hline SV & DF & SS & MS & F \\
\hline Genotypes (G) & 4 & 519.01 & 129.75 & $5.63^{* *}$ \\
Environments (E) & 7 & 179.17 & 25.60 & $1.11^{\text {NS }}$ \\
Gx E & 28 & 645.50 & 23.05 & $12.15^{* *}$ \\
Residual & 200 & 379.55 & 1.90 & \\
Total & 239 & & & \\
Mean & 77.23 & & & \\
CV(\%) & 1.78 & & & \\
\hline
\end{tabular}

\begin{tabular}{cc} 
Genetic parameters \\
\hline Genotypic variance $(\mathrm{Vg})$ & 2.22 \\
G×E Variance $(\mathrm{Vge})$ & 3.53 \\
Residual variance $\left(\mathrm{V}_{\mathrm{RES}}\right)$ & 1.89 \\
Mean heritability $\left(\mathrm{h}^{2}\right) \%$ & 82.23 \\
Intraclass correlation $(\mathrm{r})^{1}$ & 29.07 \\
Genetic coefficient of variation $(\mathrm{CVg})$ & 1.93 \\
$\mathrm{CVg} / \mathrm{CVe}$ Ratio & 1.08 \\
\hline
\end{tabular}

** Significant at $1 \%$ probability, Ns: not significant, SV: source of variation, DF: degrees of freedom, SS: sum of squares, MS: mean square, F: F test of analysis of variance, $C V e$ : experimental coefficient of variation, $\mathrm{CVg}$ : genetic coefficient of variation, ${ }^{1} \mathrm{r}=\mathrm{Vg} /(\mathrm{Vg}+\mathrm{Vge}+\mathrm{VRES})$.

Quality scores above 80 associated with a fine quality beverage were observed in the environments of Alto Paraíso, Ouro Preto do Oeste, and São Miguel do Guaporé. However, the clones of better beverage quality in these environments did not have the same performance in other locations. This inconsistency in the clone's behavior is caused by the unpredictable change in the plant performance grown in different environments. These results indicate that both the effects of genotypes (clones) and the effect of the GxE interaction are important for the expression of the beverage quality. Significant effects of the genotype $x$ environment interaction in coffee growing were also reported in other studies (Barbosa et al., 2012; Borém et al., 2019; Laviola et al., 2007; Fonseca et al., 2019; Moura et al., 2017).

For field experiments, estimates of the coefficient of variation lower than $10 \%$ can be considered low (PimentelGomes, 2009) (Table 4). In evaluation of a greater number of clones, Souza et al. (2018a) observed an estimate of the coefficient of variation of 13.26 in evaluation of the attributes of beverage quality of 130 genotypes of C. canephora in a single environment.

The estimates of heritability indicated predominance of the genetic component in expression of beverage quality, indicating that the effect of the plants was more important than the effect of environments on expression of this characteristic (Table 4). Souza et al. (2018a) also found that the genetic component was more important than the environmental component on expression of the quality attributes of $C$. canephora, except for the attributes uniformity and cleanness of the beverage, which did not show genetic variability in the population evaluated.

Scattering in the plane of the first two principal components allows evaluation of the performance of the clones simultaneously in all the environments, associated with reference points that represent genotypes of known behavior (centroids). The placement of the centroids in the diagram depends on the data, which limits division of the plane into quadrants. In this case, the most important criterion is the proximity of the genotypes to the reference points. Clones 25 and 05 are closer to the centroid of high general adaptability (I). Clone 03 was closer to ideotype $\mathrm{V}$, which represents the genotype of medium and constant performance in all the environments. Clones 66 and 08 were closer to the ideotype of lower adaptability in all the environments (Figure 1).

Clones 25 and 05 showed greater potential for beverage quality in the different environments (Figure 1). Silva et al., (2008) used the centroid method to calculate the distances between descriptors of beverage quality at different altitudes in 11 environments in the South of Minas Gerais and also found that at higher altitudes the coffees had the best chemical characteristics for beverage quality.

According to the quality scale proposed by the UCDA (2010), clone 25 had a special beverage, with a score above 80 points in environments $\mathrm{A} 2$ and $\mathrm{A} 8$, and clone 05 in environment A5. Clone 25 had the best performance over all the environments, whereas clone 05 had the best performance in the unfavorable environments (Table 5).

The mean scores of the coffee clones evaluated characterize the beverage as "very good". Similar results were reported by Pereira et al. (2019) in a study on C. canephora in different environments in Espírito Santo. These scores were followed by the sensory profile of different genotypes of Coffea sp. in Ruiru in Kenya, as reported by Abdulmajid (2014), where the Robusta genotype originating from Uganda achieved 78.50 points in this sensory evaluation.

Cultivated for their better field performance, none of the clones presented final scores of beverage quality over 80 points with stability in the evaluated environments (Table 5). Bovi et al. (2018) evaluated the beverage quality of 13 clones of the variety Conilon Vitória (INCAPER 8142) and identified differences among the scores. Four clones had scores below 35.3 points, three clones had scores from 47.5 to 67.5 points, and the others had scores from 77.5 to 82.8 points. In a study conducted by Souza et al. (2018b), five varieties of C. canephora and different coffee bean drying systems were evaluated; in this case, the quality scores were lower than 70 points. The low scores and problems found in the coffee may be related to the harvest and to post-harvest processing because the lots consisted of coffee at different stages of maturity. 


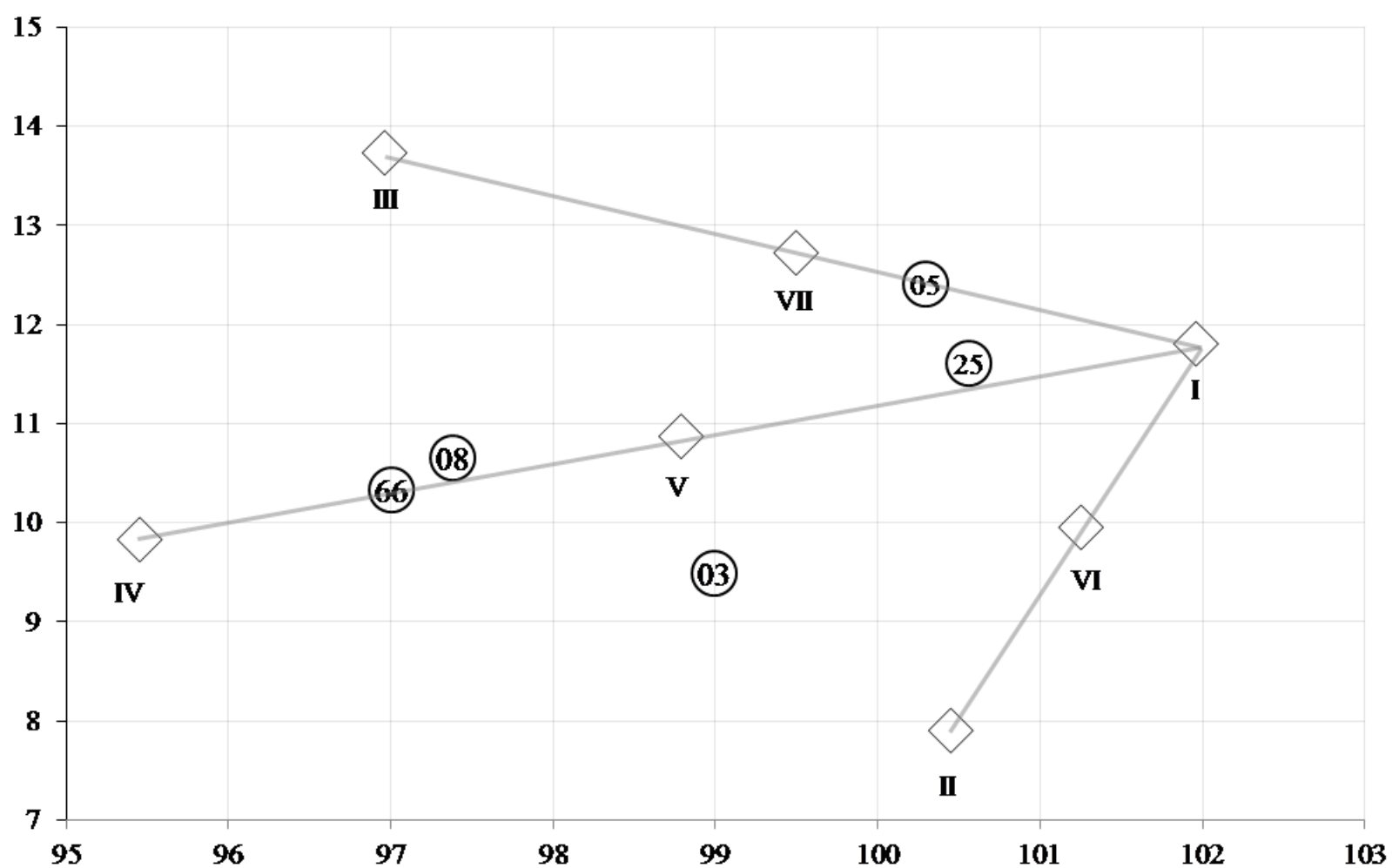

Figure 1: Scatter plot of the first two principal components of the final score of beverage quality of the five $C$. canephora clones most grown in the Western Amazon evaluated in eight different environments. The points with Roman numerals represent the reference points of general and specific adaptability to the environments evaluated: I: high general adaptability (Maxf, Maxd), II: adaptability specific to favorable environments (Maxf, Mind), III: Adaptability to unfavorable environments (Minf, Maxd), IV: little adapted (Minf, Mind), V: high stability, low adaptability (Medf, Medd), VI: adaptability specific to favorable environments (Maxf, Medd), VII: adaptability specific to unfavorable environments (Medf, Maxd).

Table 5: Selection gain and beverage quality final scores of the main C. canephora clones grown in the Western Amazon, evaluated in eight environments.

\begin{tabular}{ccccccccccccc}
\hline Clone & $\mathrm{A}_{1}$ & $\mathrm{~A}_{2}$ & $\mathrm{~A}_{3}$ & $\mathrm{~A}_{4}$ & $\mathrm{~A}_{5}$ & $\mathrm{~A}_{6}$ & $\mathrm{~A}_{7}$ & $\mathrm{~A}_{8}$ & $\mathrm{P}_{\mathrm{i}}$ overall & $\mathrm{P}_{\mathrm{i}}$ fav & $\mathrm{P}_{\mathrm{i}}$ unfav & Mean $^{1}$ \\
\hline 03 & 75.6 & 75.2 & 76.5 & 75.4 & 79.2 & 79.7 & 79.5 & 72.0 & 3 & 3 & 4 & 76.6 \\
05 & 78.7 & 77.7 & 79.7 & 79.8 & $\mathbf{8 0 . 3}$ & 77.4 & 78.7 & 79.1 & 2 & 2 & 1 & $78.9 *$ \\
08 & 76.2 & 77.0 & 76.4 & 76.8 & 75.8 & 76.7 & 76.8 & 75.2 & 4 & 4 & 3 & 76.4 \\
25 & 77.0 & $\mathbf{8 1 . 4}$ & 78.2 & 79.0 & 79.0 & 78.7 & 78.2 & $\mathbf{8 0 . 6}$ & 1 & 1 & 2 & $79.0 *$ \\
66 & 74.3 & 76.8 & 75.3 & 75.3 & 76.8 & 78.8 & 73.3 & 75.3 & 5 & 5 & 5 & 75.7 \\
$\mathrm{M}_{\mathrm{o}}$ & 76.4 & 77.6 & 77.2 & 77.3 & 78.6 & 78.2 & 77.3 & 76.4 & & & & \\
$\mathrm{M}_{\mathrm{s}}$ & 77.8 & 79.5 & 78.9 & 79.4 & 79.6 & 78.0 & 78.4 & 79.8 & & & \\
$\mathrm{SD}$ & 1.5 & 1.9 & 1.7 & 2.1 & 1.0 & -0.2 & 1.1 & 3.4 & & & \\
$\mathrm{GS}$ & 1.4 & 1.8 & 1.7 & 1.9 & 0.9 & 0.0 & 1.1 & 3.4 & & & \\
$\mathrm{GS} \%$ & 1.8 & 2.3 & 2.2 & 2.5 & 2.4 & 0.0 & 2.2 & 4.4 & & &
\end{tabular}

A1: Alto Alegre dos Parecis - RO, $A_{2}$ Alto Paraíso - RO, $A_{3}$ : Cacoal - RO, $A_{4}$ : Nova Brasilândia - RO, $A_{5}$ : Ouro Preto do Oeste - RO, $A_{6}$ : Porto Velho - RO, $A_{7}$ : Rolim de Moura - RO, $A_{8}$ : São Miguel do Guaporé - RO. $P_{i}$ overall: Estimate of general adaptability of Lin Binns, $P_{i}$ fav: Estimate of adaptability to favorable environments of Lin Binns, $P_{i}$ unfav: Estimate of adaptability to unfavorable environments of Lin Binns. *Superior clones. MO: mean of beverage quality evaluated in each environment, MS: Mean of the selected clones 05 and 25, SD: Selection differential, GS: gain from selection, GS\%: gain from selection percentage. 
The attributes that most stood out were flavor and the bitterness/sweetness relationship, with scores higher than 7.3. Flavor corresponds to the main characteristic of the coffee and is equivalent to the scores of the first impressions, from the first aroma and taste, up to the final aftertaste during the cupping process (SCA, 2013). For the uniformity and cleanness attributes, maximum scores (10) were obtained in all the evaluations; that means that the samples did not have defects that lowered the sensory evaluation.

To determine the bitterness/sweetness relationship, the cupper evaluates relative bitterness on a scale from 1 to 6 , attributing the highest number of points to the lowest bitterness perceived, and evaluates relative sweetness on a scale from 1 to 6 , giving the greatest number of points to the highest sweetness perceived. The two scores are then added to determine the result of the bitterness/sweetness relationship (SCA, 2013); in this study, sweetness exceeded bitterness. The scores of all the attributes of the sensory profile of the clones were higher than the values observed by Fonseca et al. (2019), with a mean score of 75.58 points in the 2016/2017 crop season in the state of Espírito Santo.

In the state of Rondônia, Souza et al. (2018a) analyzed the beverage quality of 130 clones of the Conilon and Robusta varieties and intervarietal hybrids of $C$. canephora coming from the experimental field of Embrapa in the municipality of Ouro Preto do Oeste, RO, and they obtained mean scores of $66.5,70.4$, and 71.8 points for the botanical varieties Conilon and Robusta and intervarietal hybrids, respectively.

The clones evaluated in this study were characterized with 38 sensory descriptors, some of them with similar characteristics, which were grouped in classes (Table 6). The descriptors are mainly associated with flavors that are found in nature (Mori et al., 2018; Pereira et al., 2017).
Among the groups of descriptors most cited in studies referring to coffee beverage quality are the following: floral, spicy, fruity, herby/plant-like, nutty, caramelly, wood-like, earthy, chemical, pungent, oxidized, and microbiological (Gonzáles-Rios et al., 2007). The 08 clone was the most complex, with 24 different descriptors identified, followed by clones $03,66,25$, and 05 which had $21,20,18$, and 18 descriptors, respectively.

The clones had different complexities that were not necessarily associated with greater beverage quality. This is because some sensory descriptors have a negative effect on coffee quality. Clone 25 stood out through the presence of the following descriptors: sweet, wood-like, fruity, and chocolatey. Clone 05: sweet, chocolatey, root-like, and herby. Clone 03: sweet, wood-like, herby, and spicy. Clone 08: spicy, sweet, chocolatey, and herby. Clone 66: herby, spicy, woodlike, and sweet. The study of Mori et al. (2018) identified the sensory profile of the beverage of genotypes of $C$. canephora in the state of Espírito Santo, where the descriptors of bitterness, strong, full-bodied, astringent, and residual flavor predominated. In addition, they concluded that acidity was the attribute with the greatest impact on overall beverage quality.

Clones 25 and 05 stood out with the highest numbers of descriptors related to sweetness (sweet, caramelly, syrup-like, and honey-like). According to Borém et al. (2006), sweetness is one of the flavor characteristics most desired in specialty coffees, and the presence of determined organic compounds in unroasted coffee, such as sugars, can serve as a standard in quality evaluation. Clone 66 had the highest intensity of herby and spicy descriptors, which encompasses the unripe, plant-like, and seasoning components. These attributes are not positive for quality.

Table 6: Grouping of the sensory descriptors of the main C. canephora clones grown in the Western Amazon.

\begin{tabular}{ccc}
\hline Descriptor & Organoleptic components attributed by the cuppers & Effect on coffee quality* \\
\hline Almondy & Almond, peanut, and macadamia nut & Positive \\
Cereal-like & Cereal, Basmati rice, husk, and toast & Negative \\
Sweet & Sweetness, caramel, syrup, and honey & Positive \\
Spicy & Spices, seasoning, and pepper & Positive \\
Fruity & Fruit, citric fruits, red fruits, and apple & Positive \\
Herby & Herbs, pea, cucumber, bell pepper, plant, and unripeness & Negative \\
Milky & Milk, butter, and doce de leite & Positive \\
Root-like & Roots, beets, carrot, cassava, and earth & Negative \\
Wood-like & Wood & Negative \\
Bitter & Bitterness & Negative \\
Chocolatey & Chocolate & Positive \\
Floral & Flowers & Positive \\
Medicinal & Medicine & Negative \\
Tobacco-like & Tobacco & Negative
\end{tabular}

*Evaluation taken from the SCA (2013). 
The coffees samples evaluated in this study were harvested in the cherry maturity stage, washed, and separated from unripe and defective coffee beans. Therefore, defects were not registered in sensory analysis. In reference to the sensory descriptors related to the mouth sensation attribute (Robusta Cupping Protocols), the harsh descriptor that causes a disagreeable taste bitter and astringent was identified by the cuppers. Clones 25 and 05 had the lowest percentages of descriptors related to harshness and were precisely those that achieved the highest overall mean scores for beverage quality. Clone 66, which had the highest proportion of harshness descriptors, was also the clone that had the lowest overall score for beverage quality (Table 4). It may be considered that the mouth sensation attribute is an indicator for measuring beverage quality in C. canephora.

\section{CONCLUSIONS}

The estimates of the genetic parameters indicated predominance of the genetic component in expression of beverage quality, indicating that the effect of the genotypes was more important than the effect of environments on expression of this characteristic.

- Cultivated for their better field performance, none of the clones presented final scores of beverage quality over 80 points, with stability in the evaluated environments.

- Clones 25 and 05 stood out through superior beverage quality, with a mean score near 80 points and with the highest numbers of descriptors related to sweetness.

- The complexity of sensory descriptors was not associated with greater beverage quality; sweetness was the sensory descriptor with the greatest impact on the beverage quality,

- Harshness was the descriptor with the greatest negative impact on the beverage quality of clone 66 .

\section{REFERENCES}

ABDULMAJID, A. M. Sensory evaluation of beverage characteristics and biochemical components of coffee genotypes. Advances in Food Science and Technology, 2(12):281-288, 2014.

ALVARES, C. A. et al. Koppen's climate classification map for Brazil. Meteorologische Zeitschrift, 22(6):711-728, 2013.

AVELINO, J. et al. Vers une identification de cafés-terroir au Honduras. Plantations, Recherche, Développement (Francia), (no.esp.):7-13, 2002.

BARBOSA, J. N. et al. Coffee quality and its interactions with environmental factors in Minas Gerais, Brazil.

Journal of Agricultural Science, 4(5):181-190, 2012.
BORÉM, F. M. et al. Qualidade do café submetido a diferentes temperaturas, fluxos de ar e períodos de présecagem. Coffee Science, 1(1):55-63, 2006.

BORÉM, F. M. et al. Meteorological variables and sensorial quality of coffee in the Mantiqueira region of Minas Gerais. Coffee Science, 14(1):38-47, 2019.

BOVI, H. F. et al. Qualidade física e sensorial dos treze clones do café 'Conilon Vitória' processado por via seca. In: SIMÃO, J. B. P. et al. (Orgs.). Cafeicultura no Caparaó: Resultados de pesquisas II. Alegre: Incaper, Cap. 9, p.97-108, 2018.

BUENAVENTURA, S. C. E.; CASTAÑO, C. J. J. Influencia de la altitud en la calidad de la bebida de muestras de café procedente del ecotopo 206B en Colombia. Cenicafé, 53(1):119-131, 2002.

CABRERA, S. C. A.; ACEVEDO, F. A.; LACERRA, E. J. A. Algunos índices del Coffea arábica L. a diferentes alturas del Escambray años 1986 y 1987. Centro Agrícola 18, 1(1):81-96, 1991.

\section{COMPANHIA NACIONAL DE ABASTECIMENTO -} CONAB. Acompanhamento de safra brasileira Café, v. 5 - Safra 2018, n.4 - Quarto Levantamento, Brasília, p. 1-84, dez. 2018. Available in: <http://www.conab.gov.br>. Access in: January 12, 2019.

CRUZ, C. D.; CARNEIRO, P. C. S.; REGAZZI, A. J. Modelos biométricos aplicados ao melhoramento genético. 3.ed. Viçosa: Universidade Federal de Viçosa, 2014. 668p.

DALCOMO, J. M. et al. Evaluation of genetic divergence among clones of conilon coffee after scheduled cycle pruning. Genetics and Molecular Research, 14(4):15417-15426, 2015.

DALAZEN, J. R. et al. Base genética da cafeicultura e caracterização dos principais clones cultivados no estado de Rondônia. In: PARTELLI, F. L.; ESPINDULA, M. C. (Orgs.). Café conilon: conhecimento para superar desafios. 1ed. Alegre:CAUFES, p.165-177, 2019.

EBERHART, S. A.; RUSSELL, W. A. Stability parameters for comparing varieties. Crop Science, 6(1):36-40, 1966.

ESPINDULA, M. C. et al. Café em Rondônia. In: PARTELLI, F. L.; GONTIJO, I. (Org.). Café conilon: Gestão e Manejo com Sustentabilidade. 1ed. Alegre: CAUFES, v.1, p.83-102, 2017.

FONSECA, A. S. da et al. Fuzzy logic in the spatial and temporal distribution in the quality of the beverage in conilon coffee. Coffee Science, 14(2):163-172, 2019. 
FERRÃO, L. F. V. et al. Comparative study of different molecular markers for classifying and establishing genetic relationships in Coffea canephora. Plant systematics and evolution, 299(1):225-238, 2013.

GIOMO, G. S.; BORÉM, F. M. Cafés especiais no Brasil: Opção pela qualidade. Informe Agropecuário, 32(261):7-16. 2011.

GONZÁLEZ-RÍOS, O. et al. Impact of "ecological" postharvest processing on the volatile fraction of coffee beans: II. Roasted coffee. Journal of Food Composition and Analysis, 20:297-307, 2007.

HAIR, J. F. et al. Analise multivariada de dados. Tradução Adonai Schlup Sant' Anna-6th Edition, Bookman, Porto Alegre. 2009. 688p.

LAVIOLA, B. G. et al. Alocação de fotoassimilados em folhas e frutos de cafeeiro cultivado em duas altitudes. Pesquisa Agropecuaria Brasileira, 42(11):1521-1530, 2007.

LIN, C. S.; BINNS, M. R. A superiority measure of cultivar performance for cultivar $\mathrm{x}$ location data. Canadian Journal Plant Science, 68(1):193-198, 1988.

MARCOLAN, A. L. et al. Cultivo dos cafeeiros conilon e Robusta para Rondônia. Porto Velho: EMBRAPA Rondônia, 2009. 67p. (EMBRAPA Rondônia: Sistema de Produção, 33).

MENCHÚ, E. J. F.; ORTEGA, E. Correlación entre algunas propiedades físicas del café tostado y su calidad inherente. Agronomía, 2(1):9-19, 1971.

MORAIS, H. et al. Escala fenológica detalhada da fase reprodutiva de Coffea arabica. Bragantia, 67(1):257-260, 2008.

MONTAGNON, C.; CUBRY, P.; LEROY, T. Amélioration génétique du caféier Coffea canephora Pierre: Connaissances acquises, stratégies et perspectives. Cahiers Agriculture, 21(2-3):43-153. 2012.

MORI, A. L. B. et al. Sensory profile of conilon coffee brews from the state of Espírito Santo, Brazil. Pesquisa Agropecuária Brasileira, 53(9):1061-1069, 2018.

MOSCHETTO, D. et al. Studies on the effect of genotype on cut quality of Coffea canephora. Tropical Science, 36(1):18-31, 1996.

MOURA, W. D. M. et al. Adaptability and stability of organic-grown arabica coffee production using the modified centroid method. Crop Breeding and Applied Biotechnology, 17(4):359-365, 2017.
NASCIMENTO, M. et al. Multiple centroid method to evaluate the adaptability of alfalfa genotypes. Revista Ceres, 62(1):30-36, 2015.

PEREIRA, L. L. et al. Construção de perfil sensorial para o café conilon fermentado. Revista Ifes Ciência, 5(2): 242252, 2019.

PEREIRA, L. L. et al. A complexidade de consenso entre análise sensorial, física equímica na qualidade do café. Revista Ifes Ciência, 4(2):1-13, 2018a.

PEREIRA, L. L. et al. Influence of solar radiation and wet processing on the final quality of arabica coffee. Journal of Food Quality, 1(1):1-9, 2018 b.

PEREIRA, L. L et al. Improvement of the quality of brazilian conilon through wet processing: A sensorial perspective. Agricultural Sciences, 10(3):395-411, 2019.

PEREIRA, L. L. et al. The consistency in the sensory analysis of coffees using Q-graders. European Food Research and Technology, 243(9):1545-1554, 2017.

PIMENTEL-GOMES, F. Curso de estatística experimental. 15. ed., Piracicaba: Fealq, 2009, p.451.

RAMALHO, A. R. et al. Progresso genético da produtividade de café beneficiado com a seleção de clones de cafeeiro 'Conilon'. Revista Ciência Agronômica, 47(3):516-523, 2016.

RESENDE, M. D. V. de. Genética biométrica e estatística no melhoramento de plantas perenes. 1. ed. Brasília: Embrapa Informação Tecnológica, 2002. 975p.

RIBEIRO, B. B. et al. Avaliação química e sensorial de blends de Coffea canephora Pierre e Coffea arabica L. Coffee Science, 9(2):178-186, 2014.

ROCHA, R. B. et al. Utilização do método centróide para estudo da estabilidade e adaptabilidade ao ambiente. Ciência Florestal, 15(3):255-266, 2005.

ROCHA, R. B. et al. Caracterização e uso da variabilidade genética de banco ativo de germoplasma de Coffea canephora Pierre ex Froehner. Coffee Science, 8(4):478$485,2013$.

ROCHA, R. B. et al. Adaptabilidade e estabilidade da produção de café beneficiado em Coffea canephora. Ciência Rural, 45(9):1531-1537, 2015.

ROCHA, R. B. et al. Adaptabilidade e estabilidade de progênies de meios-irmãos de pinhão-manso em diferentes regiões do Brasil. Revista Ceres, 63(2):174$182,2016$. 
RODRIGUES, W. P. et al. Physiological aspects, growth and yield of' Coffea spp. in areas of high altitude. Australian Journal of Crop Science, 10(5):666-674, 2016.

SANTOS, M. B. S. dos et al. Características físicoquímicas de grãos verdes e torrados de cultivares de café (Coffea arabica L.) do IAPAR. Coffee science, 6(3):245-255, 2011.

SPECIALTY COFFEE ASSOCIATION OF AMERICA SCA. Protocols. 2013. Available in: $<$ http://coffeetraveler. net/wpcontent/files/901SCAACuppingProtocolsTSC DocV_RevDec08_Portuguese.pdf>. Access in: June $\overline{2} 2$, 2020 .

SILVA, V. A. da et al. Qualidade do Café Produzido em Diferentes Altitudes do Sul de Minas Gerais e Processado por Via Seca. Revista em Agronegócio e Meio Ambiente, 1(2): 219-229, 2008.

SILVEIRA, A. S. de et al. Sensory analysis of specialty coffee from different environmental conditions in the region of Matas de Minas, Minas Gerais, Brazil. Revista Ceres, 63(4):436-443, 2016.

SOUZA, C. A. et al. Characterization of beverage quality in Coffea canephora Pierre ex A. Froehner. Coffee Science, 13(2):210-218, 2018a.

SOUZA, T. S. de et al. Avaliação física, química e sensorial do café conilon submetido a diferentes processos de secagem. In: SIMÃO, J. B. P. et al. (Orgs.). Cafeicultura no Caparaó: Resultados de pesquisas II. Alegre, Incaper, Cap.8, p.79-96, 2018 b.

STURM, G. M. et al. Qualidade Sensorial de Café Conilon em Diferentes Altitudes. Enciclopédia Biosfera, 6(1):1-7, 2010 .

SUPERINTENDÊNCIA DA ZONA FRANCA DE MANAUS SUFRAMA. Amazônia Ocidental. 2017. Available in: <http:// www.suframa.gov.br/invest/zona-franca-de-manausamazonia-ocidental.cfm>. Access in: June 22, 2020.

SUNARHARUM. W. B.; WILLIAMS, D. J.; SMYTH, H. E. Complexity of coffee flavor: A compositional and sensory perspective. Food Research International, 62:315-325. 2014.

TEN CATEN, A. et al. Estatística multivariada aplicada à diminuição do número de preditores no mapeamento digital do solo. Pesquisa Agropecuária Brasileira, 46(5):554-562, 2011.

VERDIN FILHO, A. C. et al. The beverage quality of Conilon coffee that is kept in the field after harvesting: Quantifying daily losses. African Journal of Agricultural Research, 11(33):3134-3140, 2016.

UGANDA COFFEE DEVELOPMENT AUTHORITY UCDA. Protocolos para Degustação do Robusta. PSCB 123/10. Londres, Inglaterra, jun. 2010. Available in: <http://dev.ico.org/documents/pscb-123-p-robusta. pdf $>$. Access in: December 15, 2018. 